\title{
Genetic control of traits associated with phosphorus use efficiency in maize by REML/BLUP ${ }^{1}$
}

\author{
Controle genético de caracteres associados à eficiência no uso de fósforo em milho \\ via REML/BLUP
}

\author{
Júlio César DoVale ${ }^{2 *}$ e Roberto Fritsche-Neto ${ }^{3}$
}

\begin{abstract}
The improvement phosphorus use efficiency (PUE) allows to reach satisfactory yields with lower costs. A breeding strategy for PUE is to increase its components, the phosphorus acquisiton efficiency (PAE) and phosphorus utilization efficiency (PUtE). Thus, this study aimed to identify: i) the relative importance of the components of PUE, in high and low phosphorus; ii) the relationship of root system length and shoot dry mass (SDM) with PUE and its components and; iii) the genetic control of traits associated with the PUE. Forty-one hybrid combinations were evaluated in two experimental environments representing contrasting conditions of availability of phosphorus: low (LP) and high (HP). A randomized block design with two replications were used in simple factorial (hybrid combination $\mathrm{x}$ availability of phosphorus) arrangement. Independently of phosphorus availability, PAE was the most important component of the PUE and non-additive genetic effects were more important to the traits associated with the PUE. It was observed that the estimates of specific combining ability for SDM and PUE, in LP and HP, showed similar behavior and magnitude, indicating that the selection based on performance of hybrid combinations for SDM, allows to obtain genotypes with high PUE.
\end{abstract}

Key words: Zea mays. Genic effect. Abiotic stress. Mixed Models.

RESUMO - O aumento da eficiência no uso de fósforo (PUE) permite alcançar produtividades satisfatórias com menores custos. Uma estratégia para melhorar esse caráter é elevar seus componentes, às eficiências na absorção (PUE) e na utilização de fósforo (PUtE). Assim, objetivou-se com esse estudo identificar: i) a importância relativa dos componentes da eficiência no uso de fósforo (PUE), em alta e baixa disponibilidade desse nutriente; ii) a relação do comprimento do sistema radicular (CR) e da massa de parte aérea seca (SDM) com a PUE e seus componentes e, iii) o controle genético dos caracteres associados à PUE. Foram avaliadas 41 combinações híbridas experimentais em duas condições contrastantes de disponibilidade de fósforo: baixa (LP) e alta (HP). Foi utilizado o delineamento em blocos ao acaso com duas repetições em esquema fatorial simples (combinação híbrida x disponibilidade de fósforo). Independentemente da disponibilidade de fósforo, a PAE foi o componente mais importante da PUE e os efeitos genéticos não aditivos apresentaram maior importância para os caracteres associados à PUE. Observou-se que as estimativas de capacidade específica de combinação para SDM e PUE em LP e HP, apresentam comportamento e magnitude semelhantes, indicando que seleção baseada no desempenho de combinações híbridas quanto a SDM, possibilita a obtenção de genótipos com alta PUE.

Palavras-chave: Zea mays. Efeito gênico. Estresse abiótico. Modelos mistos.

\footnotetext{
* Autor para correspondência

'Recebido para publicação em 17/11/2011; aprovado em 11/01/2013

Trabalho extraído da Tese de Doutorado do primeiro autor apresentada ao Departamento de Fitotecnia da UFV

${ }^{2}$ Departamento de Fitotecnia, Universidade Federal do Ceará, Av. Mister Hull ‘2977, Bloco 805, Campus do Pici, Fortaleza-CE, Brasil, 60.021-970, juliodovale@ufc.br

${ }^{3}$ Programa de Pós-Graduação em Fitotecnia, DFT/UFV, Av. P.H. Rolfs, s/n, Viçosa-MG, Brasil, 36.570-000, roberto.neto@ufv.br
} 


\section{INTRODUCTION}

Phosphorus is an essential macronutrient and one that most limits the productivity of maize in Brazil (MACHADO; MACHADO; FURLANI, 2004). Additionally, its high ability for binding to the soil through mechanisms of adsorption and precipitation, reduces the availability of this nutrient to the plants, making it an expensive raw material in maize production. Moreover global reserves of $\mathrm{P}$ which are being exploited at values of USD 40.00 a tonne, should be exhausted by the second half of the century (MURRELL; FIXEN, 2006), indicating that research aiming to develop genotypes that are more efficient in the use of this nutrient will become increasingly more important in the coming years.

Efficient use of phosphorus (PUE) has been defined as the ratio between grain production per unit of nutrient available to the plant. The two components of PUE considered in recent studies are: (i) acquisition efficiency (PAE), defined as the ability of a genotype to absorb phosphorus from the soil, and (ii) utilization efficiency (PUtE), the ability to produce grain or dry mass per quantity of phosphorus absorbed (PARENTONI; SOUZA JUNIOR, 2008). Thus greater values for the PUE can be obtained by increasing the PAE and, or PUtE.

Studies indicate that the importance of the PUE components varies according to the availability of phosphorus in the soil (WHANG; SHEN; LIAO, 2010). For Manske et al. (2001), when the availability of this nutrient is limited, the most important component of PUE is the PAE. On the other hand, under ideal conditions the PUtE proved to be the most relevant (BALEMI; SCHENK, 2009). However, Corrales et al. (2007) observed that in maize the most important component is the PAE, regardless of the availability of phosphorus. Because of this it should be noted that there is a lack of consistent information for targeting improvement programs under conditions of stress caused by low availability of the nutrient in question.

Knowledge of this information, as well as of genetic inheritance under contrasting conditions of phosphorus availability, is fundamental when guiding the breeder as to the most appropriate method of improvement to be used (YUN; KAEPPLER, 2001). Thus genetic parameters, such as general (GCA) and specific (SCA) combining ability, are very important in making inferences about genetic control of a characteristic and about the possibilities for improvement, as well as for the indication of new cultivars (BETRÁN et al., 2003).

The validation of methods for early assessment or indirect selection of plants is also of great interest in improvement programs for conditions of abiotic stress, as they accelerate the selection process, immediately allowing discarding of the less promising genotypes (MACHADO, MACHADO; FURLANI, 2004). For this, knowledge of the relationship between characteristics is necessary, especially if those of interest display low heritability, or present problems of measurement (FALCONER, 1981). To this effect, characteristics such as shoot dry mass (SDM) and the lengths of roots can be measured at any stage of development, quickly and at low cost. However, the influence of these characteristics on the PUE is still little known.

In this context, the objective was to identify: i) the relative importance of the components of PUE for high and low phosphorus availability in the soil; ii) the relation of the root and shoot dry mass to PUE and its components; and iii) the genetic control of those characteristics associated with PUE.

\section{MATERIAL AND METHODS}

Two groups of parents were used, taken from the germplasm bank of the Programa Milho of the Federal University of Viçosa - UFV. Group I (GI) - composed of seven parents $(\mathrm{p}=1,2, \ldots, 7)$ contrasting in phosphorus use efficiency (PUE), Group II (GII) - composed of seven parents $\left(p^{\prime}=1 ', 2\right.$ ', $\ldots, 7^{\prime}$ ') contrasting in nitrogen use efficiency (NUE). Through the introduction of an unbalanced inter-populational factorial involving the two groups of parents, we obtained 41 experimental hybrids. Crossbreeding was performed reciprocally, seeds of the same combination being mixed, thereby excluding any extra-chromosomal inheritance.

The 41 hybrid combinations were evaluated in two environments that represented contrasting $\mathrm{P}$ availability: low (LP) and high (HP). A randomized block design was used, with two replications in a simple factorial scheme (hybrid combination against $\mathrm{P}$ availability). The experiment was carried out in the agricultural year of 2010/11, in a greenhouse located at the Professor Diogo Alves de Mello Experimental Campus of the Department of Plant Science at UFV (2045'14" S, 42 52 ' 53" W).

The seeds were germinated in trays with individual cells, and after emergence one seedling from each hybrid combination was transplanted into a PVC cylindrical vase of $4 \mathrm{dm}^{3}$ (10 cm diameter x $50 \mathrm{~cm}$ high), in that way making up a plot. The substrate was prepared from a mixture of $50 \%$ sand washed in de-ionized water, $37.5 \%$ vermiculite and $12.5 \%$ soil (horizon ' $\mathrm{B}$ ' of a dystrophic red-yellow latossol). The soil was used to adsorb the phosphorus and not leave it readily available to the plant. 
The nutrient solution was supplied every two days from the seventh day after emergence of the seedlings. The $\mathrm{P}$ was supplied via triple superphosphate fertilizer. For LP, $34 \mathrm{mg} \mathrm{dm}^{-3}$ of $\mathrm{P}$ was added to the substrate, and for HP, $192 \mathrm{mg} \mathrm{dm}^{-3} \mathrm{P}$ was added, as per Alvarez V. et al. (2000). The remaining nutrients were supplied via nutrient solution, without the addition of $\mathrm{P}$, and containing: $1.0 \mathrm{M} \mathrm{Ca}\left(\mathrm{NO}_{3}\right)_{2} .4 \mathrm{H}_{2} \mathrm{O}, 1.0 \mathrm{M} \mathrm{MgSO}_{4} .7 \mathrm{H}_{2} \mathrm{O}$, $0.5 \mathrm{M} \mathrm{K}_{2} \mathrm{SO}_{4}, 0.32 \mathrm{mM} \mathrm{CuSO} \mathrm{CH}_{2} .5,46.0 \mathrm{mM} \mathrm{H}_{3} \mathrm{BO}_{3}$, $0.073 \mathrm{mM}\left(\mathrm{NH}_{4}\right)_{6} \mathrm{Mo}_{7} \mathrm{O}_{24}, 9.1 \mathrm{mM} \mathrm{MnCl} .4 \mathrm{H}_{2} \mathrm{O}, 0.76 \mathrm{mM}$ $\mathrm{ZnSO}_{4} .7 \mathrm{H}_{2} \mathrm{O}$ and $38.0 \mathrm{mM}$ Fe-EDTA.

The plants were harvested at vegetative stage V6, i.e. with six fully expanded leaves, 30 days after sowing, as per DoVale et al. (2012). The plant stems were separated from the root system and stored in paper bags. They were then dried in a forced-air oven at $60{ }^{\circ} \mathrm{C}$ for 72 hours until reaching constant weight, measured with analytical scales of $0.001 \mathrm{~g}$ precision.

The entire root system was evaluated by image analysis using the WinRhizo Pro 2009c software (Basic, Reg, Pro \& Arabidopsis for Root Measurement) coupled to an EPSON Expression 10000 XL scanner equipped with additional lighting (TPU), with a definition of 400 dpi, as described by Bouma, Nielsen and Koutstaal (2000). The ten classes of diameter provided by the software were simplified into two, following the methodology proposed by Trachsel et al. (2009). For lateral-root length (LRL) therefore, fragments with a diameter of less than or equal to $0.5 \mathrm{~mm}$ were taken into account, and for the axial-root length (ARL), fragments with a diameter greater than $0.5 \mathrm{~mm}$.

To quantify the P content, a $0.1 \mathrm{~g}$ sample was taken from the shoot dry mass (SDM) for each plant, and nitropercloric digestion carried out as suggested by Malavolta, Vitti and Oliveira (1989). Readings were taken with a spectrophotometer at $725 \mathrm{~nm}$. The P content was estimated from the levels present, and then extrapolated for each unit of SDM, and from that the phosphorus use efficiency was calculated with its components, the Pacquisition efficiency (PAE) and P utilization efficiency (PUtE), as proposed by Moll, Kamprath and Jackson (1982):

$$
\begin{aligned}
& \mathrm{PAE}=\frac{\mathrm{P}_{\text {(acquisition) }}}{\mathrm{P}_{\text {(available) }}}\left(\mathrm{mg} \mathrm{mg}^{-1}\right) \\
& \mathrm{PUtE}=\frac{\text { SDM }}{\mathrm{P}_{\text {(acauisition) }}}\left(\mathrm{mg} \mathrm{mg}^{-1}\right)
\end{aligned}
$$

PUE $=$ PAE $x$ PUtE $\left(m g \mathrm{mg}^{-1}\right)$

In mixed-model analysis, the model effects are not tested by the F-test, as is done in the varianceanalysis method. In that case, the likelihood ratio test (LRT) is recommended for any random effects in which a framework similar to that for variance analysis is elaborated, referred to as Deviance Analysis (ANADEV), and established through the following steps (FRITSCHENETO, 2011): i) obtain the point of maximum for the logarithm of the residual-likelihood function ( $\log \mathrm{L})$ for models with and without the effect being tested; ii) obtain the deviance $\mathrm{D}=-2 \log \mathrm{L}$ for models with and without the effect to be tested; iii) obtain the difference between deviances for models with and without the effect being tested, getting the likelihood ratio (LR); iv) testing the significance of this difference by LRT, using the chisquare with 1 degree of freedom, these estimates tending to have this type of distribution.

To obtain the variance components and estimates of the genetic parameters, the data were submitted to analysis by the Restricted Maximum Likelihood/Best linear unbiased prediction (REML/BLUP) method, as described by Resende (2002). Initially individual analyses are made for every availability of $\mathrm{P}$ using the following model:

$\mathrm{y}=\mathrm{Xr}+\mathrm{Zm}+\mathrm{Wf}+\mathrm{Tc}+\mathrm{e}$

where: $\mathbf{y}$ is the vector of the phenotypic averages of the hybrid combinations; $\mathbf{r}$ is the vector of the repetition effects (assumed to be fixed) added to the overall mean; $\mathbf{m}$ is the vector of the effects of the genitors of Group II (assumed to be random), in which $m \sim N(0, M)$, being $M=I \sigma_{m}^{2} ; \mathbf{f}$ is the vector of the effects of genitors from Group I (assumed to be random), where $f \sim N(0, F)$, being $F=I \sigma_{\mathrm{f}}^{2}$; c is the vector of the effects of the specific combining ability of Group I with II (assumed to be random), where $c \sim N(0, C)$, being $C=I \sigma^{2}$; and $\mathbf{e}$ the error vector, where, $e \sim N(0, R)$ and $\mathrm{R}=I \sigma_{\mathrm{e}}^{2} . \mathbf{X}, \mathbf{Z} \mathbf{W}$ e $\mathbf{T}$ are incidence matrices which display the effects of $\mathbf{r}, \mathbf{m}, \mathbf{f}$, and $\mathbf{c}$ on the $\mathbf{y}$ vector respectively.

The mixed-model equations for the prediction of $r$, $\mathrm{m}, \mathrm{f}$ and $\mathrm{c}$ are equal to:

$$
\begin{aligned}
& {\left[\begin{array}{cccc}
X^{\prime} X & X^{\prime} Z & X^{\prime} W & X^{\prime} T \\
Z^{\prime} X & Z^{\prime} Z^{\prime} \lambda_{1} & Z^{\prime} W & Z^{\prime} T \\
W^{\prime} X & W^{\prime} Z & W^{\prime} W+\lambda_{2} & W^{\prime} T \\
T^{\prime} X & T^{\prime} Z & T^{\prime} W & T^{\prime} T+\lambda_{3}
\end{array}\right]\left[\begin{array}{c}
r \\
m \\
f \\
c
\end{array}\right]=\left[\begin{array}{c}
X^{\prime} y \\
Z^{\prime} y \\
W^{\prime} y \\
T^{\prime} y
\end{array}\right]} \\
& \text { where } \quad \lambda_{1}=\frac{1-h_{m}^{2}-h_{f}^{2}-h_{c}^{2}}{h_{m}^{2}}, \quad \lambda_{2}=\frac{1-h_{m}^{2}-h_{f}^{2}-h_{c}^{2}}{h_{f}^{2}} \quad \text { and } \\
& \lambda_{3}=\frac{1-h_{m}^{2}-h_{f}^{2}-h_{c}^{2}}{h_{c}^{2}} \text {, and where } h_{m}^{2} \text { the narrow sense }
\end{aligned}
$$

heritability of the genitors of GI, that of GII, and $h^{2}$ the coefficient of determination of the effects of the SCC of GI com GII. 
Subsequently the joint analyses were performed for the two availabilities of $\mathrm{P}$, using the simplified model:

$\mathrm{y}=\mathrm{Xr}+\mathrm{Zg}+\mathrm{Wi}+\mathrm{e}$

where: $\mathbf{y}$ is the vector of the phenotypic means of the hybrid combinations; $\mathbf{r}$ is the vector of the repetition effects within the availabilities of $\mathrm{P}$ (assumed to be fixed), added to the overall mean; $g$ is the vector of genotypic effects (assumed to be random), where $g \sim N(0, G)$, and where $G=I \sigma^{2}{ }_{\mathrm{g}} ; \mathbf{i}$ is the vector of the interaction between hybrid combination and availability of $\mathrm{P}$ (assumed to be random), where $i \sim N\left(0, I_{g a}\right)$, and where $I_{\mathrm{ga}}=I \sigma_{\mathrm{ga}}^{2}$; and $\mathbf{e}$ the error vector, where $e \sim N(0, R)$ and $R=I \sigma_{\mathrm{e}}^{2} . \mathrm{X}, \mathrm{W}$ and $\mathrm{Z}$ are incidence matrices which display the effects of $\mathbf{r}, \mathbf{g}$, and $\mathbf{i}$ on the y vector respectively.

The mixed-model equations for the prediction of $\mathbf{r}$, g e $\mathbf{i}$ are equal to:

$$
\left[\begin{array}{ccc}
X^{\prime} X & X^{\prime} Z & X^{\prime} W \\
Z^{\prime} X & Z^{\prime} Z+\lambda_{1} & Z^{\prime} W \\
W^{\prime} X & W^{\prime} Z & W^{\prime} W+\lambda_{2}
\end{array}\right]\left[\begin{array}{l}
r \\
g \\
i
\end{array}\right]=\left[\begin{array}{c}
X^{\prime} y \\
Z^{\prime} Y \\
W^{\prime} y
\end{array}\right]
$$

where $\quad \lambda_{1}=\frac{1-h_{g}^{2}-h_{i}^{2}}{h_{g}^{2}}$ and $\lambda_{2}=\frac{1-h_{g}^{2}-h_{i}^{2}}{h_{i}^{2}}$, being the broad sense $h^{2}{ }_{i}$ the coefficient of determination of the interaction between hybrid combination and availability of $\mathrm{P}$.

To solve the mixed-model equations and obtain the genetic values, the genetic and non-genetic components of variance were assumed to be unknown. These were estimated by the REML method, using the SELEGEM-REML/BLUP statistical package software (RESENDE, 2007).

With a view to obtaining the relation between the responses of the hybrid combinations under low and high $\mathrm{P}$ availability $\left(r_{\mathrm{HP} \times \mathrm{LP}}\right)$, the correlation between the rankings of these combinations was estimated, taking into consideration the performance of the same characteristic at both availabilities of P. For this, we used the Spearman correlation coefficient of rank $(\rho)$, expression (8):

$$
\rho=\frac{1-6 \sum d_{i}^{2}}{n\left(n^{2}-1\right)}
$$

where $\mathrm{d}^{2}$ is the difference between the ranking of each corresponding value at LP and HP, and $n$ the number of pairs of values.

\section{RESULTS AND DISCUSSION}

Under low phosphorus availability, the genitors of GI showed significant differences for the effect of general combining ability (GCC) as well as for the efficiencies of the acquisition and utilization of phosphorus (Table 1). However, the genitors of GII differed for the CGA effect only in root length. These results were expected, as they had been identified in a preliminary experiment, genitors with contrasting PUE and components making up GI, and genitors with contrasting EUN making up GII, proving that the identification of these genitors was efficient. These differences indicate the existence of additive genetic variability, and that the genitors contribute in different ways to the transmission of alleles that control the expression of PUE components. Under high phosphorus availability, no significant differences were identified between the genitors of GI and GII for the GCA effect as regards the evaluated traits.

As regards the effects of specific combining ability (SCA), at both availabilities of phosphorus, significant differences for most of the studied traits were observed, among them the efficient use of phosphorus. This shows that regardless of the availability of this nutrient, the hybrid combinations showed significant deviations from the average behavior of the genitors. Additionally great differences were found between the estimates of broad and narrow sense heritability, especially under high phosphorus availability. Thus it can be seen that the genotypic variance is mainly explained by the variance of dominance deviations, evidenced by high values of the ratio $\sigma_{d}^{2} / \sigma^{2}$. This demonstrates that the non-additive effects have greater importance for the PUE, as reported by Chen et al. (2009) using QTLs in maize. Therefore, regardless of phosphorus availability, larger genetic gains should be obtained through the use of inter-population improvement strategies (FREITAS JÚNIOR et $a l$., 2006).

For most traits, average estimates and heritability were generally lower under low phosphorus availability. According to Coque and Gallais (2006), under conditions of abiotic stress genetic variability is reduced and consequently heritability, as the genotypes tend to present a similar performance, thereby hindering selection. The exceptions were for acquisition efficiency and both utilization efficiency and usage of phosphorus efficiency. This is because these last two traits are measured as a function of shoot dry mass, which was not reduced in proportion to the availability of phosphorus. While the concentration of this nutrient was reduced by almost six times, the average production of shoot dry mass was reduced by half. 
Table 1 - Values of the likelihood ratio test (LRT) for the effects of general combining ability (GCA) for Group I (GI) and II (GII) and the effects of specific combining ability (SCA) between the two groups from the individual analyses of their deviances. Estimates of heritability both narrow $\left(h^{2}\right)$ and broad $\left(h^{2}{ }_{g}\right)$ sense, the ratio between the variance of the dominance deviations and the additive variance $\left(\sigma_{\mathrm{d}}^{2} / \sigma_{\mathrm{a}}^{2}\right)$, averages and coefficients of variation $(\mathrm{CV})$ of the shoot dry mass (SDM) in grams, length of lateral $\left(\mathrm{LR}_{\mathrm{LAT}}\right)$ and axial $\left(\mathrm{LR}_{\mathrm{AXI}}\right)$ roots in metres, acquisition efficiencies (PAE), utilization efficiencies (PUtE) and use of phosphorus efficiencies (PUE) in $\mathrm{mg} \mathrm{mg}^{-1}$, under low (LP) and high phosphorus availability (HP) in 41 hybrids of maize, Viçosa,Minas Gerais, Brazil

\begin{tabular}{|c|c|c|c|c|c|c|c|c|c|c|c|c|}
\hline \multirow{2}{*}{ Effects } & \multicolumn{2}{|c|}{ SDM } & \multicolumn{2}{|c|}{$\mathrm{LR}_{\mathrm{LAT}}$} & \multicolumn{2}{|c|}{$\mathrm{LR}_{\mathrm{AXI}}$} & \multicolumn{2}{|c|}{ PAE } & \multicolumn{2}{|c|}{ PUtE } & \multicolumn{2}{|r|}{ PUE } \\
\hline & LP & HP & LP & HP & LP & HP & LP & HP & LP & HP & LP & HP \\
\hline CGA (GI) & $1.23^{\mathrm{ns}}$ & $2.28^{\mathrm{ns}}$ & $1.77^{\mathrm{ns}}$ & $0.36^{\mathrm{ns}}$ & $0.48^{\mathrm{ns}}$ & $1.93^{\mathrm{ns}}$ & $2.72 *$ & $0.30^{\text {ns }}$ & $3.24 *$ & $0.0^{\mathrm{ns}}$ & $1.22^{\mathrm{ns}}$ & $2.26^{\mathrm{ns}}$ \\
\hline $\mathrm{CGA}(\mathrm{GII})^{1}$ & $0.00^{\mathrm{ns}}$ & $1.22^{\mathrm{ns}}$ & $8.30 * * *$ & $2.57^{\mathrm{ns}}$ & $5.32 * *$ & $0.07^{\mathrm{ns}}$ & $0.00^{\text {ns }}$ & $1.34^{\mathrm{ns}}$ & $0.82^{\text {ns }}$ & $1.04^{\mathrm{ns}}$ & $0.00^{\mathrm{ns}}$ & $1.22^{\mathrm{ns}}$ \\
\hline CEC GI x GII ${ }^{1}$ & $2.96^{*}$ & $15.77 * * *$ & $3.88 * *$ & $7.99 * * *$ & $5.82 * *$ & $22.10 * * *$ & $3.14 *$ & $3.04 *$ & $0.51^{\text {ns }}$ & $0.00^{\mathrm{ns}}$ & $2.99 *$ & $15.77 * * *$ \\
\hline$h_{a}^{2}$ & 0.04 & 0.05 & 0.24 & 0.12 & 0.13 & 0.02 & 0.06 & 0.15 & 0.34 & 0.07 & 0.04 & 0.05 \\
\hline$h_{g}^{2}$ & 0.32 & 0.66 & 0.50 & 0.56 & 0.48 & 0.74 & 0.15 & 0.36 & 0.42 & 0.07 & 0.32 & 0.66 \\
\hline$\sigma^{2} / \sigma^{2}$ & 6.95 & 12.52 & 1.09 & 3.87 & 2.72 & 28.77 & 1.29 & 1.08 & 0.25 & 7.00 & 6.95 & 12.52 \\
\hline Mean & 1.09 & 2.41 & 29.19 & 33.62 & 11.30 & 11.85 & 0.02 & 0.02 & 517.29 & 179.33 & 8.11 & 3.14 \\
\hline $\mathrm{CV}(\%)$ & 28.61 & 19.85 & 14.87 & 17.71 & 17.71 & 13.91 & 43.78 & 30.29 & 12.94 & 22.99 & 28.61 & 19.85 \\
\hline
\end{tabular}

${ }^{1}$ Values obtained by the likelihood ratio test (LRT). ${ }^{* *}$ Significant at $\mathrm{P}=0.01, * * \mathrm{P}=0.05, \mathrm{P}=0.10$ and $*$ ns not significant by the $\chi 2$ test with one degree of freedom

Both of the availabilities of phosphorus were contrasting enough to differentiate between the performance of the hybrid combinations as regards most of the traits, except for root length (Table 2).

It was found that the effect of hybrid combinations produced a significant difference in the traits of shoot dry mass and the efficiencies of the acquisition and of the utilization of phosphorus. The genetic variance detected in the joint analysis corresponds to the average variance detected in all the environments evaluated, except for the interaction between genotype and environment. For this reason, when working with contrasting environments it is common for the genetic variability seen in each environment, such as those found for lateral and axial root lengths, and for the acquisition efficiency, to be "swallowed up" by their respective interactions in the joint analysis. However, the hybrids responded differently when subjected to conditions of low and high phosphorus availability, as evidenced by the significant effects of the interaction between hybrid combination and phosphorus availability ( $\mathrm{HC} \times \mathrm{P})$, with the exception of usage efficiency. This shows that selection

Table 2 - Estimates of $F$ values calculated for the effect of phosphorus availability and the likelihood ratio test (LRT), for the effects of hybrid combination, and the interaction of hybrid combination and phosphorus availability from the joint deviance analyses. Estimates of broad-sense heritability $\left(h^{2}\right)$, correlations between hybrid performance under the availabilities of phosphorus $\left(r_{\mathrm{HP} \times \mathrm{LP}}\right)$, means and coefficients of variation $(\mathrm{CV})$ of the shoot dry mass $(\mathrm{SDM})$ in grams, length of lateral $\left(\mathrm{LR}_{\mathrm{LAT}}\right)$ and axial $\left(\mathrm{LR}_{\mathrm{AXI}}\right)$ roots in metres, acquisition efficiencies (PAE), utilization efficiencies (PUtE) and use of phosphorus efficiencies (PUE) in mg mg-1 $\mathrm{mnder}^{-1}$ low and high phosphorus availability in 41 hybrids of maize, Viçosa,Minas Gerais, Brazil

\begin{tabular}{|c|c|c|c|c|c|c|}
\hline Effects & SDM & $\mathrm{LR}_{\mathrm{LAT}}$ & $\mathrm{LR}_{\mathrm{AXI}}$ & PAE & PUtE & PUE \\
\hline Phosphorus availability $(\mathrm{P})^{1}$ & $10.69 * *$ & $0.76^{\mathrm{ns}}$ & $0.09^{\mathrm{ns}}$ & $4.08 *$ & $35.05 * *$ & $8.52 * *$ \\
\hline Hybrid combinations $(\mathrm{HC})^{2}$ & $8.01 * * *$ & $0.36^{\mathrm{ns}}$ & $0.8^{\mathrm{ns}}$ & $4.85 *$ & $0.11^{\mathrm{ns}}$ & $8.01 * * *$ \\
\hline $\mathrm{CH} \times \mathrm{P}^{2}$ & $29.74 * * *$ & $38.87 * * *$ & $53.1 * * *$ & $8.54 * * *$ & $2.02^{\mathrm{ns}}$ & $29.74 * * *$ \\
\hline$h_{g}^{2}$ & 0.34 & 0.48 & 0.55 & 0.21 & 0.01 & 0.28 \\
\hline 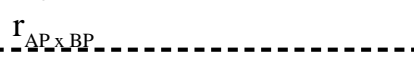 & 0.58 & 0.91 & 0.90 & 0.85 & 0.05 & 0.79 \\
\hline Mean & 1.75 & 31.57 & 11.61 & 0.02 & 346.95 & 5.63 \\
\hline $\mathrm{CV}(\%)$ & 23.12 & 16.09 & 16.10 & 36.69 & 16.46 & 30.24 \\
\hline
\end{tabular}

${ }^{1}$ Valores de $F$ calculado, testados com 1 e 40 graus de liberdade. Significant at $\mathrm{P}=0.0 \mathrm{a} * *$ and ${ }^{\mathrm{NS}}$ not significant by the F-test; ${ }^{2}$ Valores obtidos pelo teste da razão de verossimilhança (Likelihood Ratio Test - LRT). Significant at $* * * \mathrm{P}=0.01, * * \mathrm{P}=0.05$, $* \mathrm{P}=0.10$ and ${ }^{\text {ns }}$ not significant by the $\chi 2$ test with one degree of freedom 
should be performed for specific environments and not according to average behavior, because the alleles that control the expression of a particular characteristic when the nutritional supply is low are at least in part different to those alleles which control that same characteristic under ideal supply conditions (SOUZA et al., 2009). However, the correlation between the performance of hybrid combinations under high and low phosphorus availability $\left(r_{\mathrm{HP} \times \mathrm{LP}}\right)$, presented estimates of medium to high magnitude for most traits evaluated, except for utilization efficiency. This is indicative of a simple interaction (RESENDE, 2002), as it reflected the consistency of genotype superiority even when the availability of $\mathrm{P}$ changed, i.e. those hybrid combinations with a superior performance under low phosphorus supply were also the best when the supply was high Thus maize hybrids can be evaluated in a single environment (of either low or high availability) and the decisions taken for that environment will be the same for other environments (FALCONER, 1981). In this way resources, time and labour could be saved.

The coefficients of variation for both the individual and joint deviance analyses were relatively high for some traits. They are however in the range observed in other studies of this nature, i.e. of abiotic stress (CIARELLI et al., 1998; FRITSCHE-NETO et al., 2010), indicating good experimental precision and high reliability of the estimates.

Most of the estimates of genetic correlation $\left(r_{\mathrm{g}}\right)$ presented coefficients of medium to high magnitude regardless of the availability of $\mathrm{P}$ (Table 3 ). The estimates for the correlation between shoot dry mass and lateral and axial root length indicate that increases in mass in the upper portion of the plant can bring about an increase in the root system. Consequently, greater root lengths should cause increases in acquisition efficiency, both under low and high phosphorus availability.

The positive and significant correlations detected between root length and both availabilities of phosphorus, demonstrate the existence of a hierarchical dependency between them, that is, as an increase occurs in the length of the axial matrices, more points of emergence of the lateral roots appear. Thus larger uptake zones are created, which assists in the acquisition of phosphorus.

Significant negative correlation between the efficiency of phosphorus acquisition and utilization were seen under both the availabilities of this nutrient. In the initial stages maize plants probably absorb more nutrients than they use. During development the importance of the usage component, rather than that of acquisition, is increased. Thus both in the initial and more advanced stages, the components of nutrient usage efficiency do not show proportionality. Under low availability, the effects of GCA for both components were significant, however not enough for the effect of PUE to be significant too (Table 1). Whang, Shen and Liao (2010) reported that it was not possible to obtain an increase in both components under any given condition of phosphorus availability. According to these authors, the genetic variability detected for PUE under low availability was due to the acquisition efficiency, with the effect of usage efficiency being ignored. Panigrahy, Rao, Sarla (2009) observed a similar effect in rice; Manske, et al. (2001) in wheat, and Zhao et al. (2004) in the soybean. On the other hand, under high phosphorus availability usage efficiency appears to be the main component of EUP (WHANG; SHEN; LIAO, 2010), and thus increases for that characteristic should be achieved by an increase in the other. Balemi and Schenk (2009) observed the same in the potato. However the results of this work are in full agreement with those obtained by Corrales et al. (2007) and Parentoni and Souza Júnior (2008), where they observed that the acquisition efficiency was the most important component of PUE regardless of the availability of phosphorus. This fact is evidenced in this study by the positive and high magnitude correlations (0.91 under low phosphorus availability and 0.92 under high) between acquisition efficiency and PUE.

Table 3 - Estimates of genotypic correlations between shoot dry mass (SDM) in grams, length of lateral roots $\left(\mathrm{LR}_{\mathrm{LAT}}\right)$ and axial $\left(\mathrm{LR}_{\mathrm{AXI}}\right)$ in meters, acquisition efficiencies (EAP), utilization efficiency (PUtE) and use of phosphorus (PUE) efficiency in $\mathrm{mg} \mathrm{mg}^{-1}$ at low (upper diagonal) and high $\mathrm{P}$ availability (lower diagonal) in 41 hybrids of maize, Viçosa, Minas Gerais, Brazil

\begin{tabular}{cllllll}
\hline & $\mathrm{SDM}$ & $\mathrm{LR}_{\mathrm{LAT}}$ & $\mathrm{LR}_{\mathrm{AXI}}$ & $\mathrm{PAE}$ & $\mathrm{PUtE}$ & $\mathrm{PUE}$ \\
\hline $\mathrm{SDM}$ & & $0.48^{* *}$ & $0.76^{* *}$ & $0.91^{* *}$ & $-0.62^{* *}$ & $1.00^{* *}$ \\
$\mathrm{LR}_{\mathrm{LAT}}$ & $0.79 * *$ & & $0.59 * *$ & $0.44^{* *}$ & $-0.34^{*}$ & $0.48^{* *}$ \\
$\mathrm{LR}_{\mathrm{AXI}}$ & $0.89^{* *}$ & $0.83^{* *}$ & & $0.48^{* *}$ & $-0.18^{\mathrm{ns}}$ & $0.76^{* *}$ \\
$\mathrm{PAE}$ & $0.92^{* *}$ & $0.62^{* *}$ & $0.91^{* *}$ & & $-0.82^{* *}$ & $0.91^{* *}$ \\
$\mathrm{EUtP}$ & $0.24^{\mathrm{ns}}$ & $0.38^{*}$ & $-0.01^{\mathrm{ns}}$ & $-0.39 *$ & & $-0.62^{* *}$ \\
$\mathrm{PUE}$ & $1.00^{* *}$ & $0.79^{* *}$ & $0.89 * *$ & $0.92^{* *}$ & $-0.25^{\mathrm{ns}}$ & \\
\hline
\end{tabular}

Significant at $* * \mathrm{P}=0.01,{ }^{*} \mathrm{P}=0.05$, and ${ }^{\mathrm{ns}}$ not significant by the t-test 
Another result which highlights the greater importance of acquisition efficiency for PUE in maize is the existence of significant negative correlation between usage efficiency and PUE under low phosphorus availability, as well as the lack of correlation between the two under high availability. Under the latter in particular, the lack of relationship between these characteristics is indicative of a reduction in allelic diversity regarding the use of this nutrient, since modern cultivars are almost entirely selected for their responsiveness when under high nutritient availability.

Despite positive and significant correlation between root length and PUE having been seen, it's probably not possible to select more efficient genotypes based on these root traits. Fritsche-Neto et al. (2010) and Pereira (2011) found that the high correlation between the traits mentioned above is due to the high indirect effect by way of shoot dry mass, whether under ideal conditions of phosphorus availability or under stress caused by the low supply of this nutrient. For these authors, traits such as shoot mass and acquisition efficiency can provide greater impact in terms of genetic gain. Based on this information, there having been found positive linear correlation between shoot dry mass and PUE under both conditions of P availability, and also having found that PAE was the most important component in explaining the differences in PUE under both availabilities of phosphorus, only estimates of
GCA and SCA for the traits of shoot dry mass and phosphorus acquisition and usage efficiencies were presented.

Those parent plants with high, positive values for the effects of GCA usually have higher averages for the crossings in which they are involved than the overall average of the hybrid combinations. Therefore, those genitors are the main contributors to the increase in the expression of the characteristic, while those with high, negative values contribute to a reduction. To this effect, it was observed that generally the GI genitors contributed more significantly to the expression of shoot dry mass and to both phosphorous usage and acquisition efficiencies regardless of the availability of phosphorus (Table 4).

For the GI genitors, under high phosphorus availability it was noted that the estimates of GCA for efficient acquisition did not differ significantly from zero, as mentioned above. Thus it can be seen that the genitors of this group should contribute little to an increase in acquisition, and that the genitors of GII, such as 3' and 7', should reduce it. Nevertheless, it was found that certain hybrid combinations, such as $4 \times 2$ ' and $6 \times 4$ ' stood out at low availability, and 4x1', 6x2', $6 \times 3$ ', $4 \times 2$ ' and $6 \times 5$ ' at high availability (Table 5). It was therefore noted that genitors 4 and 6 , identified as having the highest GCA at low phosphorus availability, contributed most to the increase in PAE at both the availabilities of this nutrient.

Table 4 - Estimates of general combining ability for shoot dry mass (SDM), acquisition efficiency (PAE) and use of phosphorus efficiency (PUE), under low (LP) and high (HP) P availability for 14 parents of maize, based on their 41 hybrid combinations, Viçosa, Minas Gerais, Brazil

\begin{tabular}{lcccccc}
\hline \multirow{2}{*}{ Parents } & \multicolumn{2}{c}{ SDM } & \multicolumn{2}{c}{ PAE } & \multicolumn{2}{c}{ PUE } \\
\cline { 2 - 7 } & LP & HP & LP & HP & HP \\
\hline 1 & -0.030 & -0.113 & -0.001 & 0.000 & -0.220 & -0.148 \\
2 & -0.002 & 0.143 & -0.001 & 0.000 & -0.012 & 0.187 \\
3 & -0.001 & 0.040 & 0.000 & 0.000 & -0.006 & 0.052 \\
4 & 0.039 & 0.045 & 0.002 & 0.000 & 0.287 & 0.056 \\
5 & 0.022 & -0.008 & 0.000 & 0.000 & 0.160 & -0.010 \\
6 & 0.036 & -0.023 & 0.003 & 0.000 & 0.271 & -0.031 \\
7 & -0.065 & -0.079 & -0.003 & 0.000 & -0.480 & -0.103 \\
1 & 0.001 & 0.010 & 0.000 & 0.001 & 0.004 & 0.013 \\
2, & 0.000 & 0.001 & 0.000 & 0.000 & 0.003 & 0.002 \\
3, & -0.003 & -0.008 & 0.000 & -0.001 & -0.021 & -0.010 \\
4, & -0.001 & -0.003 & 0.000 & 0.000 & -0.014 & -0.004 \\
5, & 0.001 & -0.005 & 0.000 & 0.000 & 0.005 & -0.007 \\
6 & 0.003 & 0.016 & 0.000 & 0.001 & 0.020 & 0.020 \\
7, & 0.001 & -0.011 & 0.000 & -0.001 & 0.004 & -0.015 \\
\hline
\end{tabular}


Table 5 - Acquisition (PAE) and use of phosphorus (PUE) efficiencies in $\mathrm{mg} \mathrm{mg}^{-1}$ for low (LP) and high (HP) P availability, estimated in 41 corn hybrid-combinations from 14 parents, Viçosa -MG, Brazil

\begin{tabular}{|c|c|c|c|c|c|c|}
\hline \multirow{2}{*}{ Hybnrid Combination } & \multicolumn{2}{|c|}{ SDM } & \multicolumn{2}{|c|}{ PAE } & \multicolumn{2}{|c|}{ PUE } \\
\hline & LP & HP & LP & HP & LP & HP \\
\hline $\mathrm{CH} 1 \times 1$ & 0.016 & -0.722 & 0.000 & -0.004 & 0.119 & -0.940 \\
\hline $\mathrm{CH} 1 \times 2$ & -0.106 & 0.232 & -0.001 & 0.000 & -0.787 & 0.302 \\
\hline $\mathrm{CH} 1 \times 3$ & 0.057 & 0.305 & 0.000 & 0.000 & 0.425 & 0.397 \\
\hline $\mathrm{CH} 1 \times 5$ & 0.080 & 0.366 & 0.000 & 0.002 & 0.595 & 0.477 \\
\hline $\mathrm{CH} 1 \times 6$ & 0.142 & 0.287 & 0.001 & 0.000 & 1.059 & 0.373 \\
\hline $\mathrm{CH} 1 \times 7$ & -0.119 & 0.862 & 0.000 & 0.002 & -0.888 & 1.122 \\
\hline $\mathrm{CH} 2 \times 1$, & 0.026 & 0.179 & 0.000 & 0.000 & 0.194 & 0.233 \\
\hline $\mathrm{CH} 2 \times 4$ & 0.033 & 0.336 & 0.000 & 0.003 & 0.245 & 0.437 \\
\hline $\mathrm{CH} 2 \times 5$ & 0.127 & 0.918 & 0.000 & 0.004 & 0.943 & 1.195 \\
\hline CH 2x6' & -0.139 & -1.258 & -0.001 & -0.005 & -1.036 & -1.638 \\
\hline $\mathrm{CH} 3 \times 1{ }^{\prime}$ & -0.076 & -0.376 & 0.000 & -0.002 & -0.563 & -0.489 \\
\hline $\mathrm{CH} 3 \times 2$ ' & -0.057 & 0.267 & 0.000 & 0.000 & -0.427 & 0.348 \\
\hline $\mathrm{CH} 3 \times 4$ & -0.004 & 0.269 & 0.000 & 0.002 & -0.028 & 0.350 \\
\hline $\mathrm{CH} 3 \times 5^{\prime}$ & 0.037 & -0.128 & 0.000 & 0.000 & 0.274 & -0.167 \\
\hline $\mathrm{CH} 3 \times 6$ & -0.309 & -0.573 & -0.001 & -0.002 & -2.296 & -0.746 \\
\hline $\mathrm{CH} 3 \times 7$ & 0.006 & -0.475 & 0.000 & -0.002 & 0.047 & -0.619 \\
\hline $\mathrm{CH} 4 \mathrm{x} 1{ }^{\prime}$ & 0.094 & 0.400 & 0.000 & 0.005 & 0.697 & 0.521 \\
\hline $\mathrm{CH} 4 \times 2$ ' & 0.122 & 1.269 & 0.002 & 0.003 & 0.911 & 1.652 \\
\hline $\mathrm{CH} 4 \times 4$ & -0.085 & -0.126 & 0.000 & 0.000 & -0.633 & -0.163 \\
\hline $\mathrm{CH} 4 \times 5$ & -0.187 & -0.667 & 0.000 & -0.003 & -1.388 & -0.868 \\
\hline $\mathrm{CH} 4 \times 6^{\prime}$ & -0.016 & -0.422 & 0.000 & -0.002 & -0.121 & -0.550 \\
\hline $\mathrm{CH} 4 \times 7$ & -0.187 & -0.812 & -0.001 & -0.003 & -1.387 & -1.057 \\
\hline CH 5x1' & -0.094 & -0.405 & 0.000 & -0.002 & -0.697 & -0.527 \\
\hline $\mathrm{CH} 5 \times 2$ & 0.019 & -0.334 & 0.000 & 0.001 & 0.138 & -0.435 \\
\hline CH 5x3' & 0.044 & 0.101 & 0.000 & 0.001 & 0.327 & 0.132 \\
\hline CH 5x4' & -0.004 & -0.270 & 0.000 & -0.001 & -0.032 & -0.351 \\
\hline $\mathrm{CH} 5 \times 5$ & -0.021 & 0.053 & 0.000 & -0.001 & -0.153 & 0.069 \\
\hline CH 5x6' & 0.223 & 0.477 & 0.001 & 0.003 & 1.660 & 0.621 \\
\hline $\mathrm{CH} 5 \times 7$ & -0.077 & -0.327 & 0.000 & -0.002 & -0.573 & -0.426 \\
\hline CH 6x1' & -0.183 & -0.645 & 0.000 & -0.004 & -1.359 & -0.840 \\
\hline $\mathrm{CH} 6 \times 2$ & 0.000 & 0.547 & 0.000 & 0.005 & -0.003 & 0.712 \\
\hline CH 6x3' & -0.068 & 0.414 & 0.000 & 0.005 & -0.502 & 0.540 \\
\hline CH 6x4' & 0.221 & 0.406 & 0.002 & 0.002 & 1.645 & 0.528 \\
\hline $\mathrm{CH} 6 \times 5$ & 0.284 & 0.271 & 0.001 & -0.001 & 2.110 & 0.353 \\
\hline CH 6x6' & 0.120 & 1.051 & 0.000 & 0.001 & 0.894 & 1.368 \\
\hline $\mathrm{CH} 7 \mathrm{x} 2$ ' & 0.011 & - & 0.000 & - & 0.083 & - \\
\hline $\mathrm{CH} 7 \times 3$ & -0.039 & -0.265 & 0.000 & -0.001 & -0.293 & -0.346 \\
\hline $\mathrm{CH} 7 \times 4^{\prime}$ & 0.121 & -0.057 & 0.000 & -0.001 & 0.899 & -0.074 \\
\hline $\mathrm{CH} 7 \times 5$ & -0.163 & -0.918 & 0.000 & -0.004 & -1.213 & -1.195 \\
\hline $\mathrm{CH} 7 \times 6$ & 0.245 & 0.114 & 0.001 & 0.000 & 1.820 & 0.149 \\
\hline $\mathrm{CH} 7 \times 7^{\prime}$ & -0.095 & -0.343 & 0.000 & -0.002 & -0.704 & -0.446 \\
\hline
\end{tabular}


The SCA estimates showed the importance of genes with non-additive effects, emphasizing the importance of non-additive interactions which result from the genetic complementation between parent plants. Additionally, positive and negative estimates were observed for dry shoot mass and phosphorus acquisition and for the usage efficiencies under both availabilities (Table 5). Thus under low phosphorus supply, the hybrid combinations that contributed most to the increase in production of shoot dry mass were $6 \times 5$ ', 7x6', 5x6' e $6 \times 4^{\prime}$, while those that contributed most under high availability were $4 \times 2$ ' and $6 \times 6$ '. For the development of open-pollinated varieties (OPV), in addition to a high SCA, it is recommended that in crossings there be at least one genitor with high GCA (BETRÁN et al., 2003). Thus in addition to high values of SCA, genitor 6 stood out due to its high GCA for shoot dry mass, having taken part in the formation of the hybrid combinations $6 \times 5$ ' and $6 \times 4$ ' under low availability and $6 \times 6$ ' under high, which were among the best under the two availabilities of this nutrient This is an indication that this genotype, when used as a genitor, tends to produce OPV having a better performance for shoot dry mass, regardless of phosphorus availability.

The SCC estimates for the characteristic of shoot dry mass at both availabilities of phosphorus showed the same behavior and similar magnitudes to those observed for PUE, so that there was no change in the order of the hybrid combinations. This indicates that the selection of maize genotypes with high PUE can be carried out using dry shoot mass. For Bignotto et al. (2000), that characteristic is an indicator of productivity. This is a result of the harvest index (HI), which is that fraction of grain produced in relation to dry-plant mass. In maize, these values, which are close to 0.60 , have remained stagnant for decades (RAUN; SANDERS; OLSON, 1989). In this sense, additional values in dry shoot mass may imply increased productivity, and should therefore be a characteristic used in plant-improvement programs.

\section{CONCLUSIONS}

1. Regardless of the availability of phosphorus, the acquisition efficiency is the most important component of the efficiency of the use of phosphorus in maize;

2. The perfect association between shoot dry mass and the efficient use of phosphorus allows for the indirect selection of this second traits using the first;

3. The non-additive genetic effects are more important for those characteristics associated with the efficient use of phosphorus, so that selection should be made by the performance of the hybrid combinations;

4. The interaction between hybrid combination and availability of phosphorus is mainly of the simple type, so that selection can be performed on a single availability of phosphorus.

\section{REFERENCES}

ALVAREZ V., V. H. et al. Determinação e uso do fósforo remanescente. In: Desertificação, o Brasil busca soluções. Boletim Informativo: Sociedade Brasileira de Ciência do solo, v. 25, p. 27-32, 2000 .

BALEMI, T.; SCHENK, M. K. Genotypic variation of potato for phosphorus efficiency and quantification of phosphorus uptake with respect to root characteristics. Journal Plant Nutrition Soil Science, v. 172, n. 2, p. 669-677, 2009.

BETRÁN, F. J. et al. Genetic analysis of inbred and hybrid grain yield under stress and nonstress environments in tropical maize. Crop Science, v. 43, n. 3, p. 807-817, 2003.

BIGNOTTO, E. A. et al. Desempenho de cultivares modernos de milho em relação a cultivares primitivos em uso no sul de Minas Gerais In: CONGRESSO BRASILEIRO DE MILHO E SORGO, 13., 2000, Uberlândia. Anais... SBMS: (CD-ROM).

BOUMA, T. J.; NIELSEN, K. L.; KOUTSTAAL, B. Sample preparation and scanning protocol for computerised analysis of root length and diameter. Plant Soil, v.218, n. 1-2, p.185196, 2000.

CHEN, J. et al. Identification of QTLs for phosphorus utilization efficiency in maize (Zea mays L.) across P levels. Euphytica, v. 167, n. 2, p. 245-252, 2009.

CIARELLI, D.M. et al. Genetic variation among maize genotypes for phosphorus-uptake and phosphorus-use efficiency in nutrient solution. Journal of plant nutrition, v. 21, n. 10, p. 2219-2229, 1998.

COQUE, M.; GALLAIS, A. Genomic regions involved in response to grain yield selection at high and low nitrogen fertilization in maize. Theoretical and Applied Genetics, v. 112, n. 7, p. 1205-1220. 2006.

CORRALES, I. et al. Phosphorus efficiency and root exudates in two contrasting tropical maize varieties. Journal Plant Nutrition, v. 30, n. 6, p. 887-900. 2007.

DOVALE, J.C. et al. Efeitos gênicos de caracteres associados à eficiência no uso de nitrogênio em milho. Pesquisa Agropecuária Brasileira, v. 47, n. 3, p. 385-392. 2012.

FALCONER, D.S. Introduction to quantitative genetics. $2^{\mathrm{a}}$ Ed. Longmans Green, London/New York. 1981. 279p.

FREITAS Jr., S. P. et al. Capacidade combinatória em milhopipoca por meio de dialelo circulante. Pesquisa Agropecuária Brasileira, v. 41, n. 11, p. 1599-1607, 2006. 
FRITSCHE-NETO, R. et al. Herança de caracteres associados à eficiência de utilização do fósforo em milho. Pesquisa Agropecuária Brasileira, v. 45, n. 5, p. 465-471, 2010.

FRITSCHE-NETO, R. Seleção genômica ampla e novos métodos de melhoramento do milho. 2011. 38f. Tese (Doutorado em Genética e Melhoramento). Universidade Federal de Viçosa, Viçosa.

MACHADO, C. T. T.; MACHADO, A. T.; FURLANI, A. M. C. Variação intrapopulacional em milho para características relacionadas com a eficiência de absorção e utilização de fósforo. Revista Brasileira de Milho e Sorgo, v. 3, n. 1, p. 77-91, 2004.

MALAVOLTA, E.; VITTI, G. C.; OLIVEIRA, S. A. Avaliação do estado nutricional de plantas. Piracicaba: Potafos. 1989. $201 \mathrm{p}$.

MANSKE, G. G. B. et al. Importance of P uptake efficiency versus $P$ utilization for wheat yield in acid and calcareous soils in Mexico. European Journal of Agronomy, v. 14, n. 4, p. 261-274, 2001.

MOLL, R. H.; KAMPRATH, E. J.; JACKSON, W. A. Analysis and interpretation of factors which contribute to efficiency of nitrogen utilization. Agronomy Journal, v. 74, n. 3, p. 562564, 1982.

MURREL, T. S.;FIXEN, P.E. Improving fertilizer Peffectiveness: challenges for the future. In: International Symposium on Phosphorus Dynamics in the Soil-Plant Continuum, 3. 2006, Uberlândia. Proceedings... Sete Lagoas: Embrapa Milho e Sorgo, p. 150-151.

PANIGRAHY, M.; RAO, D.N.; SARLA, N. 2009. Molecular mechanisms in response to phosphate starvation in rice. Biotechnology Advances, v. 27, n. 4, p. 389-397, 2009.

PARENTONI, S. N.; SOUZA Jr., C. L. Phosphorus acquisition and internal utilization efficiency in tropical maize genotypes.
Pesquisa Agropecuária Brasileira, v. 43, n. 7, p. 893-901, 2008.

PEREIRA, F. B. Relação entre caracteres determinantes da eficiência no uso de nitrogênio e fósforo em milho. 2011. 32 f. Dissertação (Mestrado em Genética e Melhoramento) Universidade Federal de Viçosa, Viçosa.

RAUN, W. R.; SANDERS, D. H.; OLSON, R. A. Nitrogen fertilizer carries and their placement for minimum till corn under sprinkler irrigation. Agronomy Journal, v. 81, p. 280285, 1989.

RESENDE, M. D. V. Genética biométrica e estatística no melhoramento de plantas perenes. Brasília: Embrapa Informação Tecnológica. 2002. 975p.

RESENDE, M. D. V. Selegen-Reml/Blup: Sistema estatístico e seleção genética computadorizada via modelos lineares mistos. EMBRAPA Florestas. 2007. 361p.

SOUZA, L.V. et al. Combining ability of maize grain yield under different levels of environmental stress. Pesquisa Agropecuária Brasileira, v. 44, n. 10, p. 1297-1303, 2009.

TRACHSEL, S. et al. Mapping of QTLs for lateral and axile root growth of tropical maize. Theoretical and Applied Genetics, v. 119, n. 3, p. 1413-1424, 2009.

WHANG, X.; SHEN, J.; LIAO, H. Acquisition or utilization, which is more critical for enhancing phosphorus efficiency in modern crops? Plant Science, v. 179, n. 4, p. 302-306, 2010.

YUN, S. J.; KAEPPLER, S. M. Induction of maize acid phosphatase activities under phosphorus starvation. Plant and Soil, v. 237, n. 1, p. 109-115, 2001.

ZHAO, J. et al. Characterization of root architecture in an applied core collection for phosphorus efficiency of soybean germplasm. Chinese Science Bulletin, v. 49, n. 15, 16111620, 2004. 